\title{
Human Leukocyte Antigen Profiles of Latin American Populations: Differential Admixture and Its Potential Impact on Hematopoietic Stem Cell Transplantation
}

\author{
Esteban Arrieta-Bolaños, ${ }^{1,2,3}$ J. Alejandro Madrigal, ${ }^{1,2}$ and Bronwen E. Shaw ${ }^{1,4}$ \\ ${ }^{1}$ Clinical Research Group, The Anthony Nolan Research Institute, Royal Free \& University College Medical School, \\ London NW3 2QG, UK \\ ${ }^{2}$ University College London Cancer Institute, London WC1E 6DD, UK \\ ${ }^{3}$ Centro de Investigaciones en Hematología y Trastornos Afines (CIHATA), Universidad de Costa Rica, 11501-2060 San José, Costa Rica \\ ${ }^{4}$ Haemato-Oncology Research Unit, Division of Molecular Pathology, The Institute of Cancer Research, London SM2 5NG, UK
}

Correspondence should be addressed to Esteban Arrieta-Bolaños, esteban.arrietabolanos@ucr.ac.cr

Received 6 August 2012; Accepted 12 October 2012

Academic Editor: Colette Raffoux

Copyright (C) 2012 Esteban Arrieta-Bolaños et al. This is an open access article distributed under the Creative Commons Attribution License, which permits unrestricted use, distribution, and reproduction in any medium, provided the original work is properly cited.

\begin{abstract}
The outcome of hematopoietic stem cell transplantation (HSCT) is shaped by both clinical and genetic factors that determine its success. Genetic factors including human leukocyte antigen (HLA) and non-HLA genetic variants are believed to influence the risk of potentially fatal complications after the transplant. Moreover, ethnicity has been proposed as a factor modifying the risk of graft-versus-host disease. The populations of Latin America are a complex array of different admixture processes with varying degrees of ancestral population proportions that came in different migration waves. This complexity makes the study of genetic risks in this region complicated unless the extent of this variation is thoroughly characterized. In this study we compared the HLAA and HLA-B allele group profiles for 31 Latin American populations and 61 ancestral populations from Iberia, Italy, Sub-Saharan Africa, and America. Results from population genetics comparisons show a wide variation in the HLA profiles from the Latin American populations that correlate with different admixture proportions. Populations in Latin America seem to be organized in at least three groups with (1) strong Amerindian admixture, (2) strong Caucasian component, and (3) a Caucasian-African gradient. These results imply that genetic risk assessment for HSCT in Latin America has to be adapted for different population subgroups rather than as a pan-Hispanic/Latino analysis.
\end{abstract}

\section{Introduction}

Hematopoietic stem cell transplantation (HSCT) is a curative therapy used for the treatment of malignant and nonmalignant hematologic diseases, congenital immune deficiencies, solid tumors, and metabolic diseases [1]. Its outcome is shaped not only by clinical factors [2], but also by the genetics of the patient-donor pair [3]. Apart from the normal compatibility defined by the human leukocyte antigen (HLA) system $[4,5]$, variation in several genetic systems is thought to have an impact on the complications experienced by patients that undergo this procedure [6].

Graft-versus-host disease (GVHD) is a major complication affecting the success of the transplant and the survival of the patients. Despite the fact that most transplants are performed with high levels of compatibility in terms of HLA, a significant proportion of these transplants is affected by GVHD. Apart from clinical factors [7], a genetic component for GVHD other than HLA has been pointed out as responsible for the occurrence of GVHD in 10/10 HLA compatible patient-donor pairs $[8,9]$. Moreover, an ethnicity-driven risk of suffering GVHD after HSCT has been identified [10, 11]. However, these studies focused on "island" populations and broader populations with low admixture proportions, and further studies in admixed populations are lacking.

Latin America is a region where the most dramatic human migrations have taken place, from the early northeastern Asian bands of hunter-gatherers that conquered the 
last continent humanity had expanded to [12], through the 16th and 17th centuries European colonization and bringing of sub-Saharan African (SSA) slaves [13], to the latest waves of immigrants from all over the world in the last two centuries [14]. This complex population history makes present Latin American Populations (LAP) possibly the most ethnically diverse on the planet. This genetic diversity is thus likely to impact the effect of genetics on HSCT and hence it is necessary to understand it in order to be able to interpret genetic association studies in this and other medical fields.

In this study, we used population genetics tools to compare the HLA profiles of 31 LAP and 61 ancestral populations in order to characterise their diversity and classify them according to their genetic makeup.

\section{Materials and Methods}

2.1. Population Samples. A selection of 92 populations from Latin America, Iberia, Italy, and sub-Saharan Africa with available DNA-based typing data for HLA-A and HLA-B allele groups was made and their details are shown in Table 1. Of these, 31 LAP were defined as populations living in this region that were not classed as Amerindian. Population samples from LAP that have emigrated to the USA and Spain were also included in the analyses.

The remaining 61 populations are native population samples from the three ancestral regions that have contributed majorly to the Latin American gene pool: Amerindians (22 populations), Caucasians from Europe (Iberians and Italians, 19 populations), and SSA (20 populations). In the Caucasian population group, a sample of Italians was selected to complement the Iberian populations in view of the important immigration from this country into some LAP. In total, the population array included 384,446 chromosomes. HLA frequency data was extracted from journal articles and/or the Allele Frequencies database website [15]. The approximate geographic location for the LAP is shown in Figure 1.

2.2. Database Construction. A database containing the frequencies for 47 HLA-A and HLA-B allele groups from the 92 populations that were selected was built. When the available data were at high resolution, the data were reduced to twodigit allele groups. The database was constructed on the Multi-Variate Statistical Package (MVSP, Kovach Computing Services, Anglesey, Wales) and was independently checked for accuracy.

2.3. Population Comparisons. The HLA-A and HLA-B profiles of the 92 populations were analysed by clustering analysis and Principal Coordinates Analysis (PCO), both based on Euclidean distances. The clustering analysis was performed dually and dendrograms were generated for both analyses. The clustering method was based on minimum variance of squared Euclidean distances with a randomized input order. The Eigenanalysis for the PCO was performed at an accuracy of $1 \mathrm{E}-7$ and axes were extracted according to Kaiser's rule [66].
Additionally, three ancestry-specific HLA allele groups were compared between population subgroups in order to illustrate the relative contribution of each ancestral population across LAP.

\section{Results}

3.1. Clustering Analysis. A dendrogram based on squared Euclidean distances was generated by the comparison of 47 HLA-A and HLA-B allele group frequencies present in the 61 ancestral populations and the 31 LAP. The results for this analysis are shown in Figure 2(a). The first split is between the Amerindian cluster and the Caucasians and SSA, which is consistent with higher differentiation of these populations. The next split is between the SSA and the Caucasian and most of the LAP.

A closer look at the clusters shows that there is a correlation between the geographic location of the ancestral populations and the branching within the clusters. Within the Amerindian cluster, 4 groups form a South American lowland group, a South American Andean group, a Central American group, and a more distinct North AmericanAlaskan group. A similar correlation is seen within the SSA cluster: western Africans split from the southern, eastern and central African populations. Some of the LAP cluster with the Amerindians, such as the Peruvian mestizos from Arequipa, or with the SSA, as the Cuban Mulattos and the Afro-Brazilians from Paraná. However, $90 \%$ of the LAP cluster within a distinct group which includes the Iberians and Italians.

The LAP-Iberian+Italian cluster splits further in distinct subgroups. Most of the Spanish populations, and minority populations from Spain, cluster in their own groups. Also, there is a broad group that clusters all of the remaining Brazilian and Cuban populations, and another one that clusters the Portuguese, Italian, and Argentinians from La Plata, the region of Cuyo, and Buenos Aires. Finally, the last cluster includes the admixed populations from Mexico, Colombia, Venezuela, Costa Rica, as well as the South American immigrants to Madrid and the Mexican and panHispanic samples from the United States.

A dual-clustering method was applied to the dataset in order to identify the groups of alleles that are most variable between the populations. The results from this analysis are shown in Figure 2(b). Clusters of signature ancestry markers can be identified, such as frequent Amerindian input allele groups (HLA-A* $68,-B^{*} 15,-A^{*} 31,-B^{*} 48,-B^{*} 40$, and $\left.-B^{*} 39\right)$, frequent Iberian and Italian Caucasian markers (HLA-A*03, $-A^{*} 29,-B^{*} 07,-B^{*} 44,-A^{*} 01$, and-B*51), and frequent alleles that are evidence of SSA genetic input (HLA$A^{*} 30,-A^{*} 23,-B^{*} 53,-B^{*} 58,-B^{*} 45$, and $-B^{*} 42$ ).

3.2. Principal Coordinates Analysis. The results from the PCO are shown in Figure 3. Firstly, the ancestral populations (Figure 3(a)) show a clear location. The first PC correlates with the Amerindian-non-amerindian split seen in the cluster analysis, whereas the second split (SSA-Caucasians) correlates with the second PC. Amerindian populations show 
TABLE 1: Summary and details of the populations included in the analyses.

\begin{tabular}{|c|c|c|c|}
\hline Code & Population & Size $(2 n)$ & Reference \\
\hline \multicolumn{4}{|l|}{ Amerindians } \\
\hline $\mathrm{ArgCh}$ & Argentinian Chiriguano & 108 & {$[15]$} \\
\hline ArgET & Argentinian Eastern Toba & 270 & {$[16,17]$} \\
\hline $\operatorname{ArgRT}$ & Argentinian Toba from Rosario & 172 & {$[15]$} \\
\hline BolA & Bolivian Aymara & 204 & {$[18]$} \\
\hline BolQ & Bolivian Quechua & 160 & {$[19]$} \\
\hline BraT & Brazilian Terena & 120 & {$[20]$} \\
\hline GuaM & Guatemalan Maya & 264 & {$[21]$} \\
\hline MexChT & Mexican Tarahumara from Chihuahua & 88 & {$[22]$} \\
\hline MexMT & Mexican Tarasco from Michoacán & 260 & {$[23]$} \\
\hline MexOMx & Mexican Mixe from Oaxaca & 110 & {$[24]$} \\
\hline MexOMxt & Mexican Mixtec from Oaxaca & 206 & {$[24]$} \\
\hline MexOZ & Mexican Zapotec from Oaxaca & 180 & {$[24]$} \\
\hline MexTH & Mexican Teenek from Huasteca region & 110 & {$[25]$} \\
\hline ParGua & Paraguayan Guaraní & 80 & {$[26]$} \\
\hline PerLC & Peruvian Lama & 166 & {$[15]$} \\
\hline PerTU & Peruvian Uro & 210 & {$[27]$} \\
\hline VenPMB & Venezuelan Bari & 110 & {$[28]$} \\
\hline VenSPY & Venezuelan Yucpa & 146 & [29] \\
\hline USAYN & Alaska Yupik Natives & 504 & {$[30]$} \\
\hline USAAI & Arizona Gila River Indian & 984 & {$[31]$} \\
\hline USAPi & Arizona Pima & 200 & {$[28]$} \\
\hline USSDS & South Dakota Lakota Sioux & 604 & {$[32]$} \\
\hline \multicolumn{4}{|l|}{ LAP } \\
\hline ArgBA & Argentinians from Buenos Aires & 2,432 & {$[15]$} \\
\hline $\operatorname{ArgCY}$ & Argentinians from Cuyo Region & 840 & {$[15]$} \\
\hline $\operatorname{ArgLP}$ & Argentinians from La Plata & 200 & {$[15]$} \\
\hline Bra & Brazilians & 216 & {$[28]$} \\
\hline $\mathrm{BraBH}$ & Brazilians from Belo Horizonte & 190 & {$[33,34]$} \\
\hline BraMG & Brazilians from Minas Gerais & 2,000 & {$[15]$} \\
\hline BraPAB & Afro-Brazilians from Paraná & 154 & {$[35]$} \\
\hline BraPCaf & Brazilian Cafuzo from Paraná & 638 & {$[35]$} \\
\hline BraPCau & Brazilian Caucasian from Paraná & 5,550 & {$[35]$} \\
\hline BraPMul & Brazilian Mulatto from Paraná & 372 & {$[35]$} \\
\hline BraPS & Brazilians from Pernambuco State & 202 & {$[36]$} \\
\hline BraSP & Brazilians from Sao Paulo & 478 & {$[15]$} \\
\hline CCVP & Costa Ricans from the Central Valley & 364 & {$[37]$} \\
\hline Chils & Chileans from Santiago & 140 & {$[15]$} \\
\hline $\mathrm{Col}$ & Colombians & 1,122 & {$[38]$} \\
\hline ColMed & Colombians from Medellin & 1,852 & [39] \\
\hline CubMx & Cubans (mixed) & 378 & {$[40]$} \\
\hline CubMu & Cuban Mulattos & 84 & {$[33,34]$} \\
\hline CubWh & Cuban Whites & 140 & {$[33,34]$} \\
\hline MadAm & Latin American immigrants in Madrid & 346 & {$[41]$} \\
\hline MexGM & Mexicans from Guadalajara & 206 & {$[42]$} \\
\hline $\mathrm{MexCM}$ & Mexicans from Mexico City & 242 & {$[43]$} \\
\hline MexSM & Mexicans from Sinaloa & 112 & {$[43]$} \\
\hline MexPM & Mexicans from Puebla & 198 & {$[43]$} \\
\hline ParM & Paraguayans & 100 & {$[44]$} \\
\hline
\end{tabular}


Table 1: Continued.

\begin{tabular}{|c|c|c|c|}
\hline Code & Population & Size $(2 n)$ & Reference \\
\hline PerA & Peruvians from Arequipa & 336 & {$[45]$} \\
\hline USHis & US Hispanics & 468 & {$[15]$} \\
\hline USHis2 & US Hispanics & 3,998 & {$[46]$} \\
\hline USHisO & US Hispanics & 3,160 & {$[47]$} \\
\hline USMex & US Mexicans & 1,106 & {$[48]$} \\
\hline VenCVM & Venezuelans from Caracas, Valencia, and Maracaibo & 192 & {$[15]$} \\
\hline \multicolumn{4}{|c|}{ Iberians and Italians } \\
\hline BasA & Basques from Arratia Valley & 166 & [49] \\
\hline BasG & Basques from Guipuskoa & 200 & {$[50]$} \\
\hline $\mathrm{C} \& \mathrm{~L}$ & Castilians & 3,880 & {$[51]$} \\
\hline CatG & Catalonians from Girona & 176 & {$[50]$} \\
\hline And & Spanish from Andalucía & 198 & {$[15]$} \\
\hline AndG & Spanish Gypsy from Andalucía & 198 & {$[15]$} \\
\hline Ibi & Spanish from Ibiza & 176 & {$[52]$} \\
\hline Maj & Majorcans & 814 & {$[52]$} \\
\hline MajJD & Majorcans of Jewish descent & 206 & {$[52]$} \\
\hline Min & Minorcans & 188 & {$[52]$} \\
\hline Mur & Murcians & 346 & {$[53]$} \\
\hline $\mathrm{NCab}$ & North Cabuernigo & 190 & {$[49]$} \\
\hline NCant & North Cantabrians & 166 & [49] \\
\hline PasV & Spanish from Pas Valley & 176 & [49] \\
\hline AzoTI & Azoreans from Terceira Island & 260 & {$[15]$} \\
\hline Ita & Italians & 318,622 & {$[54]$} \\
\hline PorC & Portuguese from central Portugal & 1,124 & {$[15]$} \\
\hline PorP & Portuguese from Porto & 15,874 & {$[15]$} \\
\hline PorF & Portuguese from Faro & 2,484 & {$[15]$} \\
\hline \multicolumn{4}{|l|}{ SSA } \\
\hline $\mathrm{CamBa}$ & Cameroon Bamileke & 154 & {$[55]$} \\
\hline CamBe & Cameroon Beti & 348 & {$[55]$} \\
\hline CamYa & Cameroon Yaounde & 184 & {$[56]$} \\
\hline CapVNW & Cape Verdeans from NW island & 124 & {$[57]$} \\
\hline CapVSE & Cape Verdeans from SE island & 124 & {$[57]$} \\
\hline CAFMP & Pygmy from the Central African Republic & 72 & {$[58]$} \\
\hline GuiB & Guineans & 130 & {$[57]$} \\
\hline Ken & Kenyans & 288 & {$[28]$} \\
\hline KenL & Kenyans-Luo & 530 & {$[59]$} \\
\hline $\mathrm{KenN}$ & Kenyans-Nandi & 480 & {$[59]$} \\
\hline MalB & Mali Bandiagara & 276 & [59] \\
\hline Moz & Mozambicans & 500 & {$[60]$} \\
\hline Rwa & Rwandans & 560 & {$[61]$} \\
\hline STIF & Sao Tome Islanders (Forro) & 132 & {$[62]$} \\
\hline SenNM & Senegalese (Madenka) & 330 & {$[63]$} \\
\hline $\mathrm{SAB}$ & Black South Africans & 400 & {$[64]$} \\
\hline Sud & Sudanese & 400 & {$[15]$} \\
\hline UgaK & Ugandan from Kampala & 350 & {$[65]$} \\
\hline ZamL & Zambians from Lusaka & 88 & [59] \\
\hline ZimHS & Zimbabwe Harare Shona & 460 & {$[28]$} \\
\hline Total & 92 & 384,446 & \\
\hline
\end{tabular}




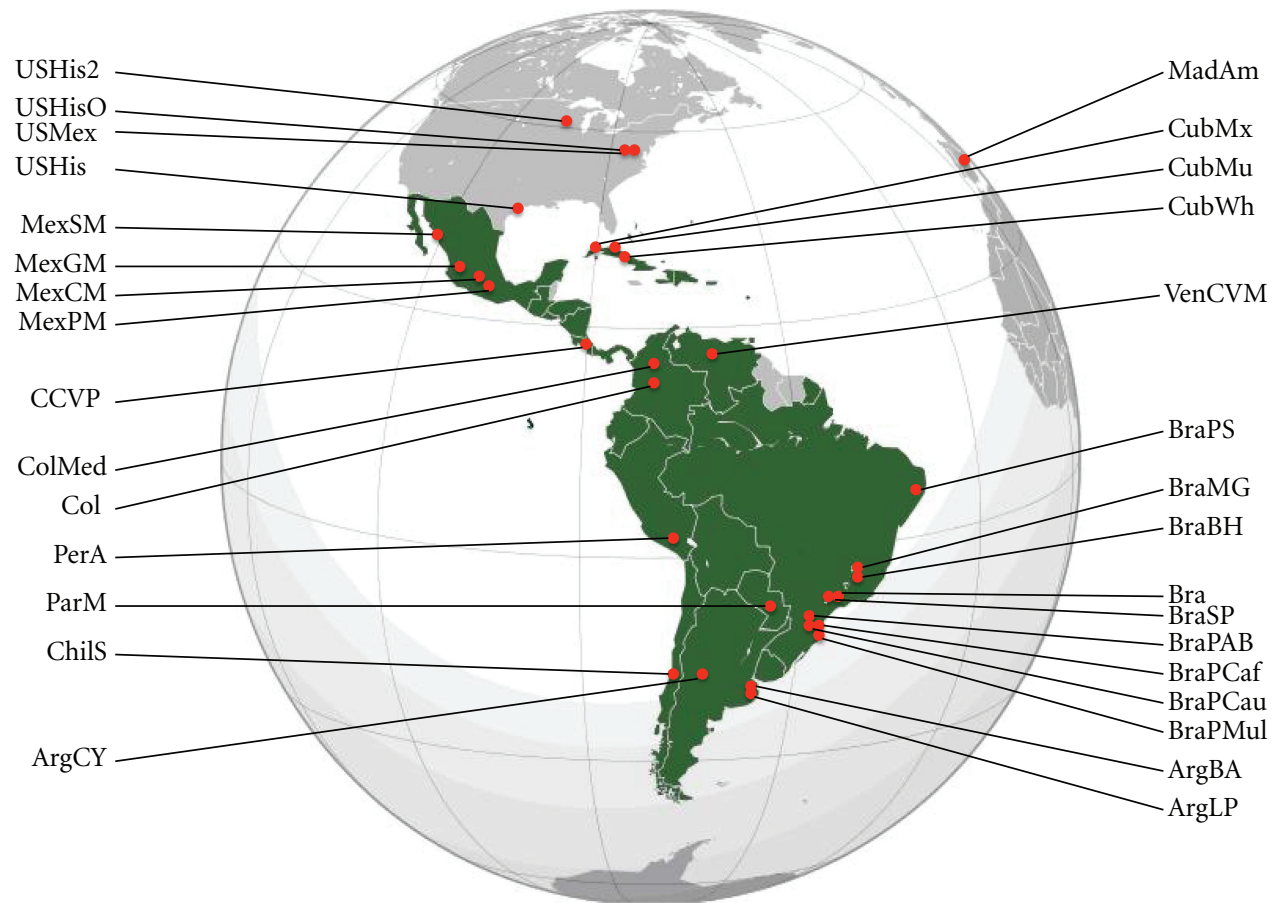

FIGURE 1: Map showing the approximate location of the LAP included in the study.

a much more dispersed array and higher distances from the Caucasians and the SSA, which is in accordance with their genetic history being shaped by the colonization of the last continent after the out-of-Africa migrations and successive bottlenecks in this process [67]. Interestingly, SSA that have been in closer genetic and geographic contact with the Caucasians, such as the Sudanese and the Cape Verdeans, are closer to these populations, whereas the southernmost Africans lie on the upper left extreme of the PCO map. Likewise, the North American Amerindians tend to be closer to the Alaskan Natives, who have been shown to be genetically different from the Amerindians of more southern regions [30].

When the LAP are included in the analysis (Figure 3(b)), the results show that LAP are located on a wide arch that connects the three ancestral populations. This arch stretches from the Peruvian mestizos from Arequipa, which appear deep into the Amerindian region, to the Afro-Brazilians from Paraná, which lie on the periphery of the SSA cluster. In between these populations there is a spectrum of locations for the remaining LAP. It is clear that there are two major regions: one that includes the LAP that lie between the Iberian and Italian populations and the Amerindian region and the others, which lie between the Caucasians and the SSA populations. Moreover, the first group seems to be divided in two subregions: one that clusters populations that lie closely to the Caucasian group (from the Argentinians from Buenos Aires to the Hispanic samples from the US), and the other (from the Mexican population from the US up to the Peruvians from Arequipa) which is dragged more intensely towards the Amerindians. The SSA component in these populations seems to be reduced, although not absent (see below). On the other hand, the populations that lie between the Caucasians and the SSA samples also cluster closely to the Iberians and Italians, but show a gradient towards the SSA cluster. This group is composed mainly by Brazilian and Cuban populations.

A few populations seem to cluster closely enough to the ancestral populations to be considered part of those clusters. This is the case of the Cuban Mulattos and the Afro-Brazilians from Paraná, the Cuban Whites, the Brazilian Caucasians from Paraná, and the Peruvians of Arequipa. In turn, it must be noted that a population classified as Amerindian, the Argentinian Toba from the city of Rosario, show significant Caucasian admixture and, consequently, lie closer to the admixed Mexicans than the Peruvians do.

3.3. Specific Ancestry Markers. To further illustrate the differential admixture patters present in LAP based on their HLA profile, 3 allele groups which are present in one of the ancestral populations and absent or nearly absent in the other two (HLA-A*25, - B* 42, and $-\mathrm{B}^{*} 48$ ) were selected in order to evaluate their frequency among the LAP groups (Figure 4). As seen in Figure 4(a), HLA-A*25, a common allele group in western Europe and virtually absent in Amerindian and SSA populations, is present more frequently in the admixed populations with strong Caucasian component (i.e., those that lie closest to the Caucasians on the Caucasian-Amerindian axis of the PCO). Interestingly, some of the ancestral populations classified as Amerindian show evidence of Caucasian admixture as demonstrated by the presence of HLA-A*25 alleles in their gene pool.

Figure 4(b) shows the frequency of the SSA allele group HLA-B $* 42$ in the 3 LAP subgroups. It is evident that these 


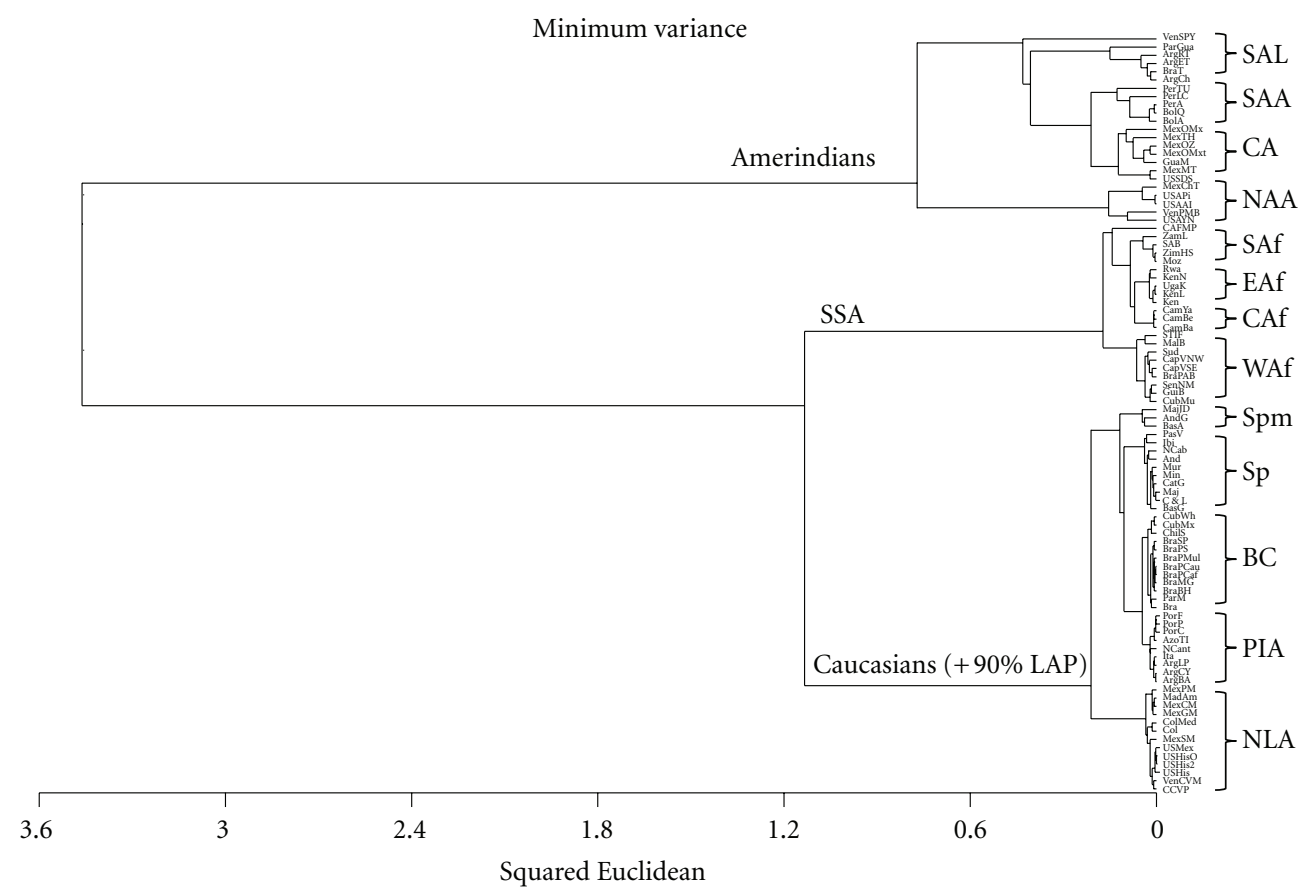

(a)

Minimum variance

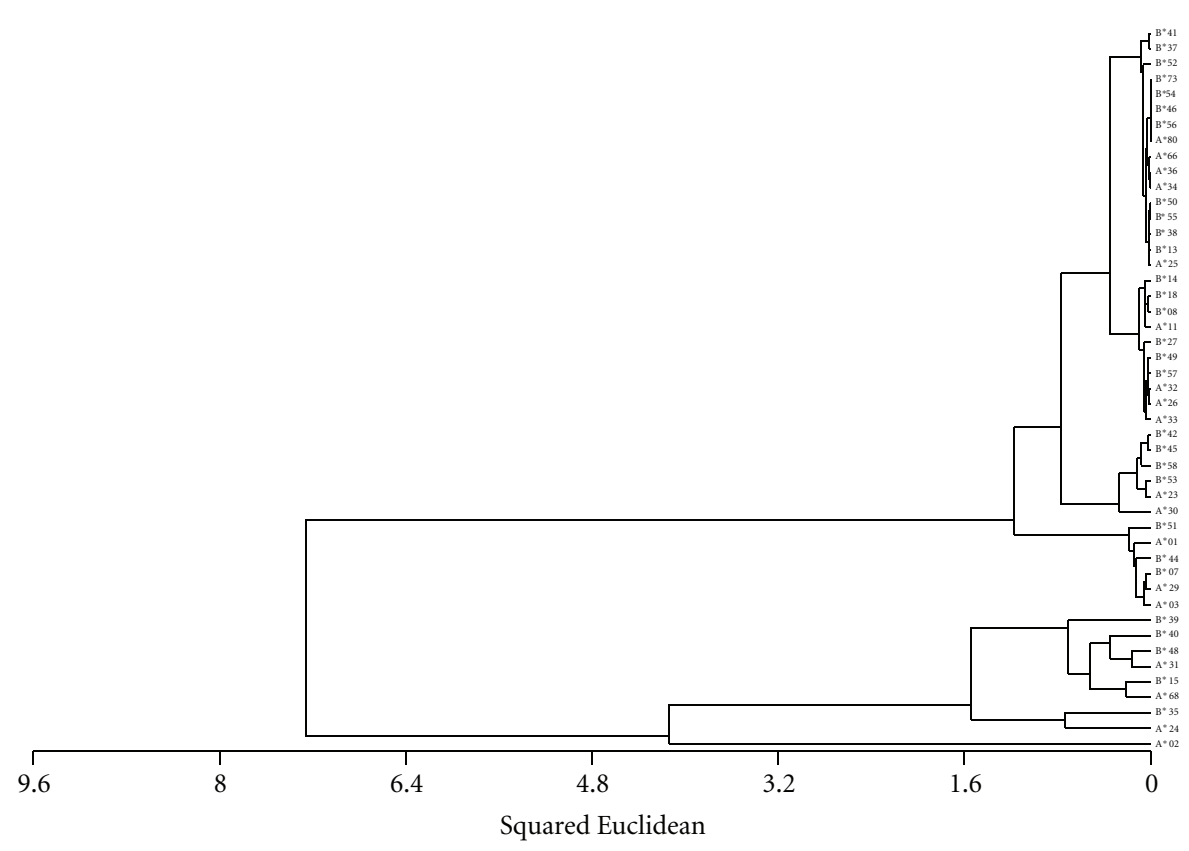

(b)

Figure 2: Cluster analysis based on 47 HLA-A and HLA-B allele group frequencies among 31 LAP and 61 ancestral populations. (a) Dendrogram showing the clustering of the 92 populations. (b) Dendrogram showing the dual-clustering of HLA allele groups in the dataset. SSA: Sub-Saharan Africans; SAL: South American Lowlanders; SAA: South American Andeans; CA: Central Americans; NAA: North Americans and Alaskans; SAf: Southern Africans; EAf, Eastern Africans; CAf: Central Africans; WAf: Western Africans; Spm: Spanish minorities; Sp: Spanish; BC: Brazilians and Cubans; PIA: Portuguese, Italians, and Argentinians; NLA: Northern Latin Americans. 


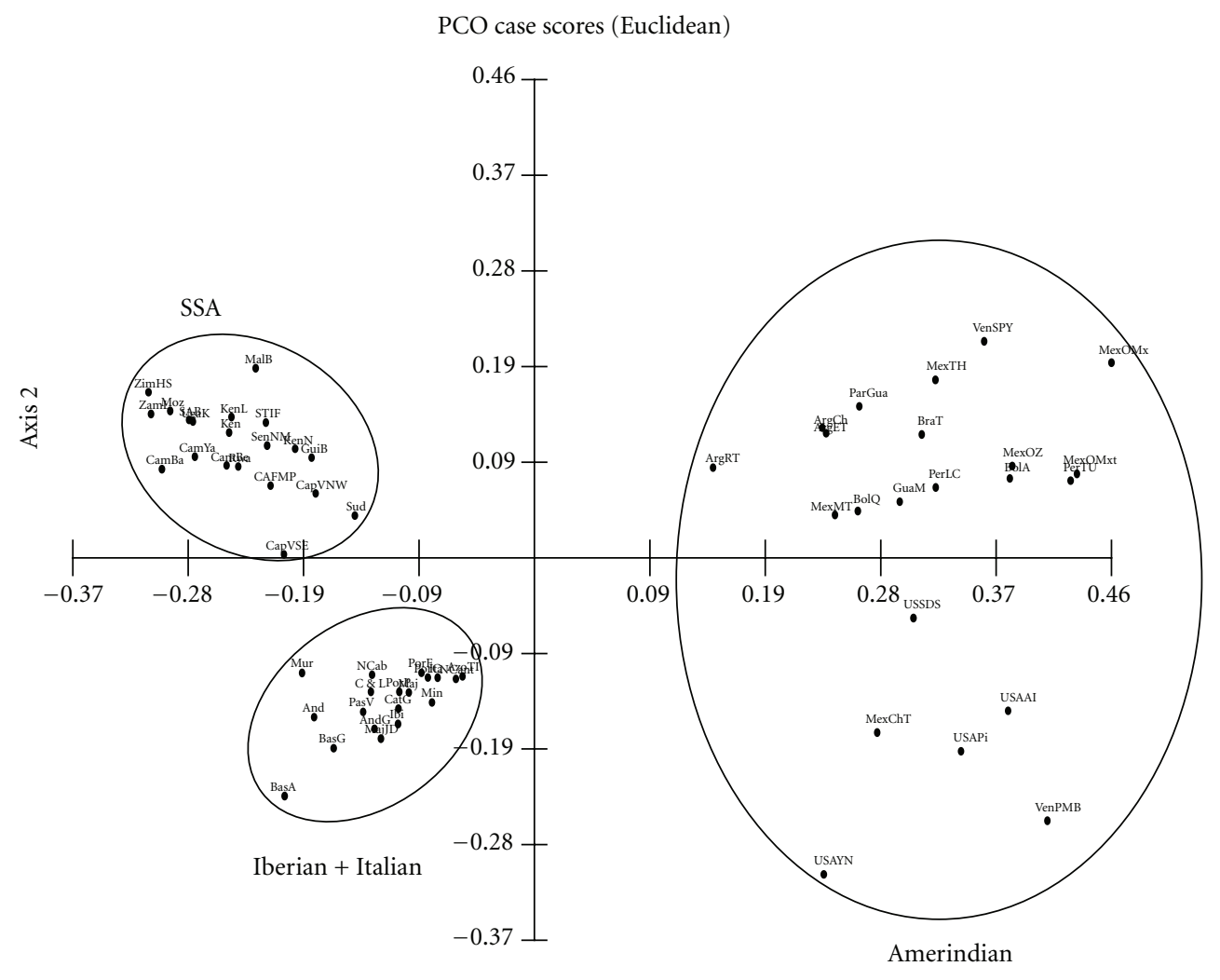

Axis 1

(a)

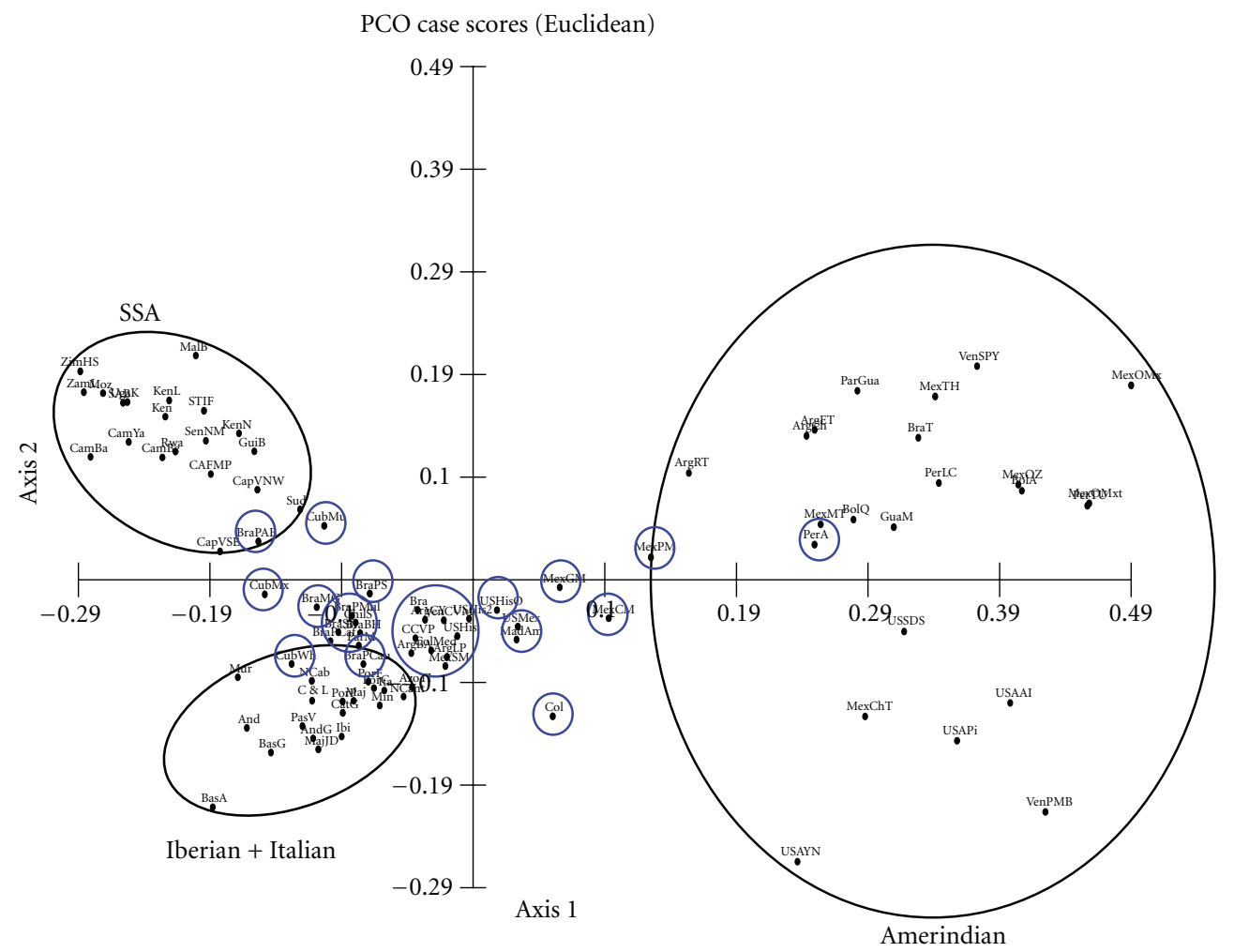

(b)

FIgure 3: Principal coordinates analysis (PCO) based on the frequencies of 47 HLA-A and HLA-B allele groups in 31 LAP and 61 ancestral populations. (a) PCO map of the first 2 principal components (57.7\% cumulative variance) for 61 ancestral populations from sub-Saharan Africa (SSA), America, and Europe. (b) PCO map showing the first 2 principal components (56.7\% cumulative variance) for 31 LAP (blue) and 61 ancestral populations. 


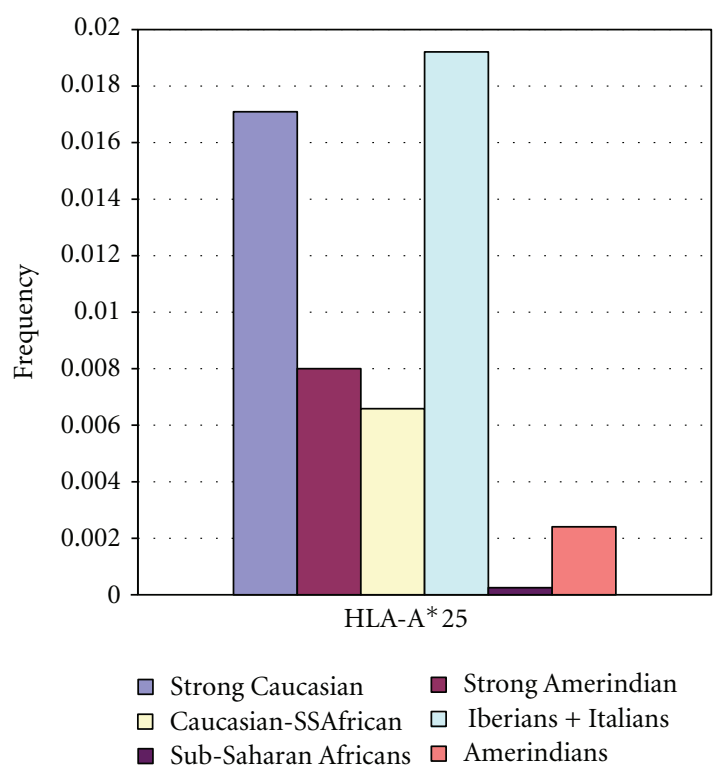

(a)

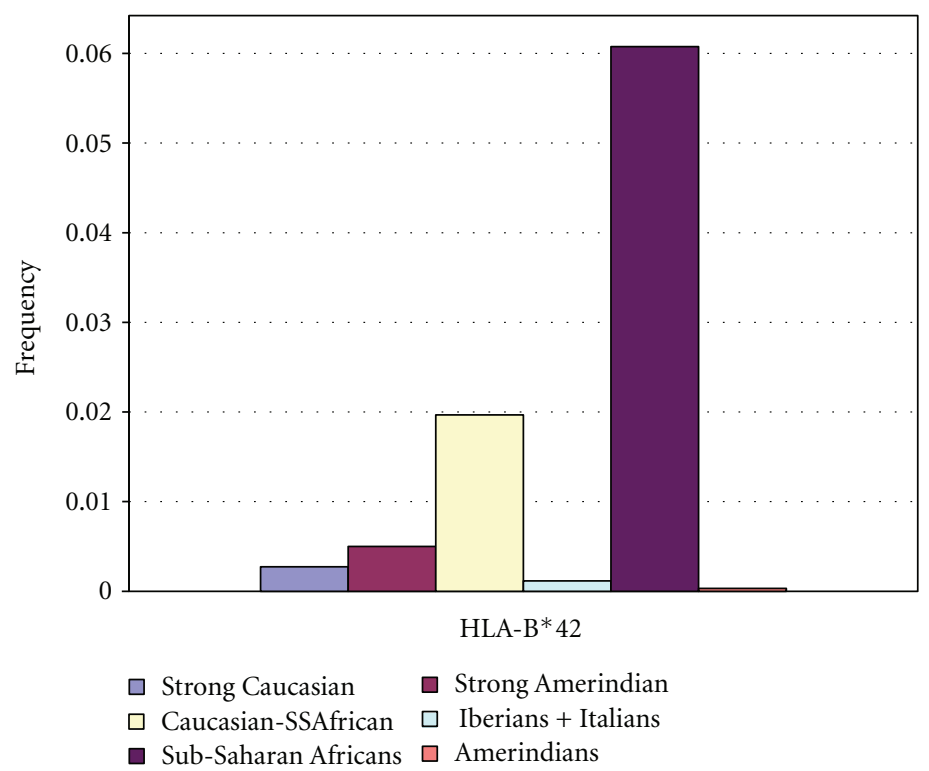

(b)

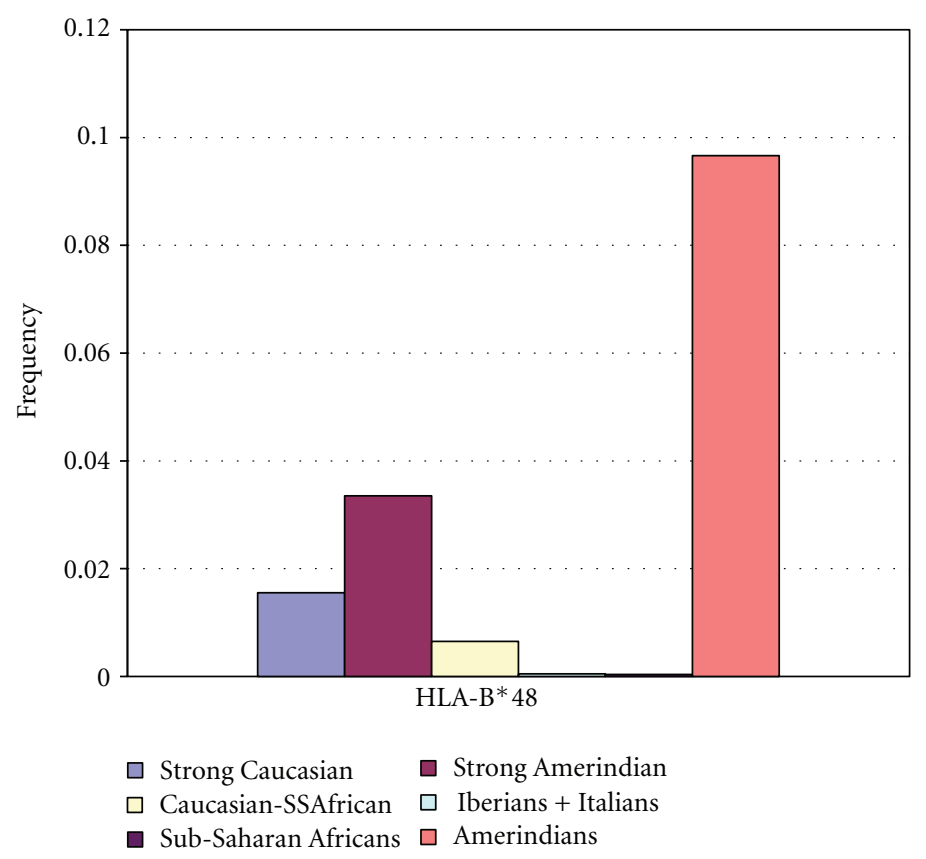

(c)

FIGURE 4: Frequency of ethnic-specific HLA allele groups among three subgroups of LAP and the ancestral populations. (a) Frequency of HLA-A*25 allele group as a Caucasian marker. (b) Frequency of HLA-B*42 allele group as a Sub-Saharan African (SSA) marker. (c) Frequency of HLA-B* 48 as an Amerindian marker.

alleles are much more frequent in these populations (mainly, Brazilian and Cuban) than in the rest. However, HLA-B*42 alleles are not absent from other LAP, which may have lower levels of SSA admixture.

Finally, Figure 4(c) shows the average frequency of HLA$\mathrm{B}^{*} 48$ alleles. This group, common in Amerindians and nearly absent from SSA and Iberian and Italian populations, is more strongly represented in the populations that form the bridge between the Amerindian and Caucasian regions in the PCO.

\section{Discussion}

The results obtained after comparing 47 HLA-A and HLA-B allele groups among the LAP and their ancestral populations show that there is widespread variation between the genetic profiles of these admixed or exported populations. In the cluster analysis it is clear that most LAP have substantial Caucasian components, with the exception of some populations such as the Peruvians from Arequipa or the Afro-Brazilians from Paraná. This is in agreement with the uneven process 
of population replacement and the collapse of many Native American groups that took place throughout the continent.

However, PCO analysis showed that most LAP sit on a wide admixture arch that approaches the ancestral clusters. A few populations fall very close to or in the ancestral clusters, but most are scattered in intermediate regions. Interestingly, population samples that are likely to be a mixture of several LAP, such as those of the USA Hispanic immigrants and the Ibero-American expatriates in Madrid, sit in the center of the distribution. In fact, the heterogeneity of the Hispanic population in the US has been described using other markers $[68,69]$, showing differential admixture patterns between areas that have received mostly Mexican immigration and those that are predominantly colonized by Caribbean islanders from Cuba and Puerto Rico. In agreement with this, US Mexicans lie slightly closer to the Amerindian side on the PCO and locate between the Mexican populations from the center and the sample from the northern state of Sinaloa. This further illustrates the heterogeneity of the Mexican populations, where a stronger Caucasian component is preserved in the north of the country [43], while the US Mexicans are likely to be a combination of northern and southern Mexican populations.

The stronger Caucasian component in some LAP can be attributed to recent European migration [14], such as that of urban populations from Argentina and some Brazilian populations, or to relatively stronger Caucasian proportions generated at colonial times in areas where Amerindian populations were low at the time of the arrival of Europeans, which is thought to be the case of the Costa Rican Central Valley and the Colombians from Medellin [70, 71].

On the Caucasian-SSA axis of admixture, several Brazilian and Cuban populations can be found. It seems that for these populations, Amerindian admixture is very low or absent. This has been noted by others [72] and it is argued that a dual admixture model is more likely to describe the patterns seen in these populations as opposed to a triple admixture model identified for other LAP. Although not included in our analysis because of the lack of molecular HLA data, serological HLA data from Panama [73] and Puerto Rico [74] suggest that these populations are likely to join this group, whereas the data from Uruguay suggest that its major population would cluster with the strong Caucasian component group [75].

Our study is limited by both the availability of population data and the need to use HLA allele group data for comparison as opposed to high-resolution allele frequencies or haplotype frequencies. It is likely that an analysis of highresolution frequencies would give finer results, but it would seriously diminish the number of populations that can be included in the analysis. However, the use of 47 allele groups from the most polymorphic genes in the human genome gives robustness to the analysis.

The effect of ethnicity on complications after HSCT has been suspected for many years $[76,77]$ but some studies have not shown such association [78]. Hence, there is growing interest in unraveling the genetic-ethnic component of GVHD in HLA-compatible HSCT. Currently, there is a project within the International Histocompatibility Working
Group that aims at analyzing the risk of GVHD after HSCT in unrelated donor pairs according to the ethnic origin of both patients and donors, based on previous findings in sibling transplantations in isolated and general populations of certain countries [10]. Preliminary results in a cohort of unrelated transplants showed that Hispanic pairs have high risks of mortality and acute GVHD (grades III-IV) only second to African American pairs. Moreover, Hispanic-Hispanic pairs had the highest risk of relapse [79]. Both analyses were carried out having Asian/Pacific (mostly Japanese) ethnically matched pairs as the reference group. These findings suggest that ethnic heterogeneity in the Hispanic population may be playing a role on the risk of complications after HSCT, and the complexity of the admixture patterns illustrated in this study and others is likely to account for much of this variation. Also, ethnicity has been associated with other complications after HSCT such as chronic GVHD [80]. Moreover, an increased risk of complications has been reported specifically for Hispanic groups in North America when compared to other ethnicities in terms of survival [81] and treatment failure [82].

It is likely that the evidence for differential outcome in different ethnic groups could be explained, at least in part, by differences in allele frequencies in genes that are relevant to the immune response and that show variable interethnic polymorphism, such as the cytokine genes [83]. Moreover, polymorphisms in other genes such as those that intervene in drug metabolism or drug targets may play a role in the way patients from different ethnicities respond to treatment in HSCT, especially in admixed populations [84, 85].

LAP show widespread variation in their genetic profiles, and this complicates genetic association studies made in these populations. There is noticeable variation not only between regions and countries, but also between areas of the same country $[43,86]$. Furthermore, the presence of minority populations of different ethnic composition adds to the complexity of population stratification in Latin America. Additionally, many populations remain to be studied. If an ethnic component is to be used as one prognostic factor affecting the risk of complications after HSCT, the application of this concept in Latin American populations will have to take into account the great diversity found among the different populations derived from this region and the different population subgroups generated by different admixture histories. Consequently, there is need of a more detailed understanding of the genetic profiles of the LAP, in order to be able to accurately stratify genetic risk in HSCT.

It is also important that a better definition of individual ancestry in LAP is reached in view of the evident limitations of both self-reported [87] and researcher-assigned ethnicities $[41,88]$. To this purpose, the use of a more objective assignment based on ancestry markers [69] is likely to increase the accuracy of the information derived from these studies. Hopefully, a finer characterization of the risk of complications after HSCT in LAP will help foresee these complications and increase the access and success of transplantation in these populations. 


\section{Acknowledgments}

This work was supported by grants from the University of Costa Rica and the Costa Rican National Council for Scientific and Technologic Research (CONICIT).

\section{References}

[1] P. Ljungman, M. Bregni, M. Brune et al., "Allogeneic and autologous transplantation for haematological diseases, solid tumours and immune disorders: current practice in Europe 2009," Bone Marrow Transplantation, vol. 45, no. 2, pp. 219 234, 2010.

[2] C. Anasetti, "What are the most important donor and recipient factors affecting the outcome of related and unrelated allogeneic transplantation?" Best Practice and Research: Clinical Haematology, vol. 21, no. 4, pp. 691-697, 2008.

[3] A. M. Dickinson, "Risk assessment in haematopoietic stem cell transplantation: pre-transplant patient and donor factors: non-HLA genetics," Best Practice and Research: Clinical Haematology, vol. 20, no. 2, pp. 189-207, 2007.

[4] S. J. Lee, J. Klein, M. Haagenson et al., "High-resolution donor-recipient HLA matching contributes to the success of unrelated donor marrow transplantation," Blood, vol. 110, no. 13, pp. 4576-4583, 2007.

[5] B. E. Shaw, R. Arguello, C. A. Garcia-Sepulveda, and J. A. Madrigal, "The impact of HLA genotyping on survival following unrelated donor haematopoietic stem cell transplantation: review," British Journal of Haematology, vol. 150, no. 3, pp. 251-258, 2010.

[6] A. M. Dickinson, "Non-HLA genetics and predicting outcome in HSCT," International Journal of Immunogenetics, vol. 35, no. 4-5, pp. 375-380, 2008.

[7] M. Jagasia, M. Arora, M. E. Flowers et al., "Risk factors for acute GVHD and survival after hematopoietic cell transplantation," Blood, vol. 119, no. 1, pp. 296-307, 2012.

[8] C. Baron, R. Somogyi, L. D. Greller et al., "Prediction of Graftversus-host disease in humans by donor gene-expression profiling," PLoS Medicine, vol. 4, no. 1, article e23, 2007.

[9] A. M. Dickinson and E. Holler, "Polymorphisms of cytokine and innate immunity genes and GVHD," Best Practice and Research: Clinical Haematology, vol. 21, no. 2, pp. 149-164, 2008.

[10] H. Oh, F. R. Loberiza, M. J. Zhang et al., "Comparison of graftversus-host-disease and survival after HLA-identical sibling bone marrow transplantation in ethnic populations," Blood, vol. 105, no. 4, pp. 1408-1416, 2005.

[11] S. Morishima, S. Ogawa, A. Matsubara et al., "Impact of highly conserved HLA haplotype on acute graft-versus-host disease," Blood, vol. 115, no. 23, pp. 4664-4670, 2010.

[12] N. Ray, D. Wegmann, N. J. R. Fagundes, S. Wang, A. RuizLinares, and L. Excoffier, "A statistical evaluation of models for the initial settlement of the american continent emphasizes the importance of gene flow with Asia," Molecular Biology and Evolution, vol. 27, no. 2, pp. 337-345, 2010.

[13] N. Brucato, O. Cassar, L. Tonasso et al., "The imprint of the Slave Trade in an African American population: mitochondrial DNA, Y chromosome and HTLV-1 analysis in the Noir Marron of French Guiana," BMC Evolutionary Biology, vol. 10, article $314,2010$.
[14] M. L. Catelli, V. Alvarez-Iglesias, A. Gomez-Carballa et al., "The impact of modern migrations on present-day multiethnic Argentina as recorded on the mitochondrial DNA genome," BMC Genetics, vol. 12, article 77, 2011.

[15] F. F. Gonzalez-Galarza, S. Christmas, D. Middleton, and A. R. Jones, "Allele frequency net: a database and online repository for immune gene frequencies in worldwide populations," Nucleic Acids Research, vol. 39, no. 1, pp. D913-D919, 2011.

[16] M. Cerna, M. Falco, H. Friedman et al., "Differences in HLA class II alleles of isolated South American Indian populations from Brazil and Argentina," Human Immunology, vol. 37, no. 4, pp. 213-220, 1993.

[17] M. A. Fernández-Viña, A. M. Lázaro, C. Y. Marcos et al., "Dissimilar evolution of B-locus versus A-locus and class II loci of the HLA region in South American Indian tribes," Tissue Antigens, vol. 50, no. 3, pp. 233-250, 1997.

[18] A. Arnaiz-Villena, N. Siles, J. Moscoso et al., "Origin of Aymaras from Bolivia and their relationship with other Amerindians according to HLA genes," Tissue Antigens, vol. 65, no. 4, pp. 379-390, 2005.

[19] J. Martinez-Laso, N. Siles, J. Moscoso et al., "Origin of Bolivian Quechua Amerindians: their relationship with other American Indians and Asians according to HLA genes," European Journal of Medical Genetics, vol. 49, no. 2, pp. 169185, 2006.

[20] A. M. Lázaro, M. E. Moraes, C. Y. Marcos, J. R. Moraes, M. A. Fernández-Viña, and P. Stastny, "Evolution of HLA-class I compared to HLA-class II polymorphism in Terena, a SouthAmerican Indian tribe," Human Immunology, vol. 60, no. 11, pp. 1138-1149, 1999.

[21] E. Gómez-Casado, J. Martínez-Laso, J. Moscoso et al., "Origin of Mayans according to HLA genes and the uniqueness of Amerindians," Tissue Antigens, vol. 61, no. 6, pp. 425-436, 2003.

[22] J. E. García-Ortiz, L. Sandoval-Ramírez, H. Rangel-Villalobos et al., "High-resolution molecular characterization of the HLA class I and class II in the Tarahumara Amerindian population," Tissue Antigens, vol. 68, no. 2, pp. 135-146, 2006.

[23] F. Loeza, G. Vargas-Alarcón, F. Andrade et al., "Distribution of class I and class III MHC antigens in the Tarasco Amerindians," Human Immunology, vol. 63, no. 2, pp. 143-148, 2002.

[24] J. A. Hollenbach, G. Thomson, K. Cao et al., "HLA diversity, differentiation, and haplotype evolution in mesoamerican natives," Human Immunology, vol. 62, no. 4, pp. 378-390, 2001.

[25] G. Vargas-Alarcón, G. Hernández-Pacheco, J. Zuñiga et al., "Distribution of HLA-B alleles in Mexican Amerindian populations," Immunogenetics, vol. 54, no. 11, pp. 756-760, 2003.

[26] O. Benitez, M. Busson, D. Charron, and P. Loiseau, "HLA polymorphism in a Guarani-Indian population from Paraguay and its usefulness for the Hispano-Indian admixture study in Paraguay," International Journal of Immunogenetics, vol. 38, no. 1, pp. 7-11, 2011.

[27] A. Arnaiz-Villena, V. Gonzalez-Alcos, J. I. Serrano-Vela et al., "HLA genes in Uros from Titikaka Lake, Peru: origin and relationship with other Amerindians and worldwide populations," International Journal of Immunogenetics, vol. 36, no. 3, pp. 159-167, 2009.

[28] S. Mack, Y. Tsai, A. Sanchez-Mazas, and H. A. Erlich, "Anthropology/ human genetic diversity population reports," in Proceedings of the 13th International Histocompatibility 
Workshop and Conference on Immunobiology of the Human Genetic Diversity Population Reports, IHWG Press, Seattle, Wash, USA, 2007.

[29] Z. Layrisse, Y. Guedez, E. Domínguez et al., "Extended HLA haplotypes in a Carib Amerindian population: the Yucpa of the Perija Range," Human Immunology, vol. 62, no. 9, pp. 9921000, 2001.

[30] M. S. Leffell, M. D. Fallin, H. A. Erlich et al., "HLA antigens, alleles and haplotypes among the Yup'ik Alaska natives: report of the ASHI Minority Workshops, part II," Human Immunology, vol. 63, no. 7, pp. 614-625, 2002.

[31] R. Williams, Y. F. Chen, R. Endres et al., "Molecular variation at the HLA-A, B, C, DRB1, DQA1, and DQB1 loci in full heritage American Indians in Arizona: private haplotypes and their evolution," Tissue Antigens, vol. 74, no. 6, pp. 520-533, 2009.

[32] M. S. Leffell, M. D. Fallin, W. H. Hildebrand, J. W. Cavett, B. A. Iglehart, and A. A. Zachary, "HLA alleles and haplotypes among the lakota sioux: report of the ASHI minority workshops, part III," Human Immunology, vol. 65, no. 1, pp. 78-89, 2004.

[33] D. Middleton, F. Williams, A. Meenagh et al., "Analysis of the distribution of HLA-A alleles in populations from five continents," Human Immunology, vol. 61, no. 10, pp. 10481052, 2000.

[34] F. Williams, A. Meenagh, C. Darke et al., "Analysis of the distribution of HLA-B alleles in populations from five continents," Human Immunology, vol. 62, no. 6, pp. 645-650, 2001.

[35] T. M. Ruiz, S. M. C. M. Da Costa, F. Ribas, P. R. Luz, S. S. Lima, and M. Da Graça Bicalho, "Human leukocyte antigen allelic groups and haplotypes in a Brazilian sample of volunteer donors for bone marrow transplant in Curitiba, Paraná, Brazil," Transplantation Proceedings, vol. 37, no. 5, pp. 2293-2296, 2005.

[36] P. Nigam, E. Dellalibera, L. Maurício-da-Silva, E. A. Donadi, and R. S. Silva, "Polymorphism of HLA class I genes in the Brazilian population from the Northeastern State of Pernambuco corroborates anthropological evidence of its origin," Tissue Antigens, vol. 64, no. 2, pp. 204-209, 2004.

[37] E. Arrieta-Bolaños, H. Maldonado-Torres, O. Dimitriu et al., "HLA-A, -B, -C, -DQB1, and -DRB1,3,4,5 allele and haplotype frequencies in the Costa Rica Central Valley Population and its relationship to worldwide populations," Human Immunology, vol. 72, no. 1, pp. 80-86, 2011.

[38] Y. R. Arias-Murillo, M. A. Castro-Jiménez, M. F. RíosEspinosa, J. J. López-Rivera, S. J. Echeverry-Coral, and O. Martínez-Nieto, "Analysis of HLA-A, HLA-B, HLA-DRB1 allelic, genotypic, and haplotypic frequencies in Colombian population," Colombia Medica, vol. 41, no. 4, pp. 336-343, 2010.

[39] L. M. Rodríguez, M. C. Giraldo, N. García et al., "Human leucocyte antigen gene (HLA-A, HLA-B, HLA-DRB1) frequencies in deceased organ donor," Biomedica, vol. 27, no. 4, pp. 537547, 2007.

[40] B. Sierra, R. Alegre, A. B. Pérez et al., "HLA-A, -B, -C, and DRB1 allele frequencies in Cuban individuals with antecedents of dengue 2 disease: advantages of the Cuban population for HLA studies of dengue virus infection," Human Immunology, vol. 68, no. 6, pp. 531-540, 2007.

[41] C. Parga-Lozano, D. Rey-Medrano, P. Gomez-Prieto et al., "HLA genes in Amerindian immigrants to Madrid (Spain): epidemiology and a virtual transplantation waiting list: amerindians in Madrid (Spain)," Molecular Biology Reports, vol. 38, no. 4, pp. 2263-2271, 2011.

[42] C. A. Leal, F. Mendoza-Carrera, F. Rivas, S. RodriguezReynoso, and E. Portilla-De Buen, "HLA-A and HLA-B allele frequencies in a mestizo population from Guadalajara, Mexico, determined by sequence-based typing," Tissue Antigens, vol. 66, no. 6, pp. 666-673, 2005.

[43] R. Barquera, J. Zúñiga, R. Hernández-Díaz et al., "HLA class I and class II haplotypes in admixed families from several regions of Mexico," Molecular Immunology, vol. 45, no. 4, pp. 1171-1178, 2008.

[44] O. Benitez, C. Dehay, C. Raffoux, and J. Colombani, "Métissage hispano-indien en Amérique du Sud: essai de compréhension grâce à l'analyse sanguine du système HLA au Paraguay," Hématologie, vol. 1, no. 5, pp. 437-439, 1995.

[45] R. De Pablo, Y. Beraún, A. Nieto et al., "HLA class I and class II allele distribution in the Peruvian population," Tissue Antigens, vol. 56, no. 6, pp. 507-514, 2000.

[46] M. Maiers, L. Gragert, and W. Klitz, "High-resolution HLA alleles and haplotypes in the United States population," Human Immunology, vol. 68, no. 9, pp. 779-788, 2007.

[47] M. S. Leffell, W. S. Cherikh, G. Land, and A. A. Zachary, "Improved definition of human leukocyte antigen frequencies among minorities and applicability to estimates of transplant compatibility," Transplantation, vol. 83, no. 7, pp. 964-972, 2007.

[48] W. Klitz, L. Gragert, M. Maiers et al., "Four-locus highresolution HLA typing in a sample of Mexican Americans," Tissue Antigens, vol. 74, no. 6, pp. 508-513, 2009.

[49] P. Sanchez-Velasco, E. Gomez-Casado, J. Martinez-Laso et al., "HLA alleles in isolated populations from north Spain: origin of the basques and the ancient Iberians," Tissue Antigens, vol. 61, no. 5, pp. 384-392, 2003.

[50] D. Comas, E. Mateu, F. Calafell et al., "HLA class I and class II DNA typing and the origin of Basques," Tissue Antigens, vol. 51, no. 1, pp. 30-40, 1998.

[51] M. Alcoceba, L. Mari'n, A. Balanzategui, M. E. Sarasquete et al., "Frequency of HLA-A, -B and -DRB1 specificities and haplotypic associations in the population of Castilla y Leon (northwest-central Spain)," Tissue Antigens, vol. 78, no. 4, pp. 249-255, 2011.

[52] C. Crespí, J. Milà, N. Martínez-Pomar et al., "HLA polymorphism in a Majorcan population of Jewish descent: comparison with Majorca, Minorca, Ibiza (Balearic Islands) and other Jewish communities," Tissue Antigens, vol. 60, no. 4, pp. 282-291, 2002.

[53] M. Muro, L. Marín, A. Torío et al., "HLA polymorphism in the Murcia population (Spain): in the cradle of the archaeologic Iberians," Human Immunology, vol. 62, no. 9, pp. 910-921, 2001.

[54] S. Rendine, I. Borelli, M. Barbanti, N. Sacchi, S. Roggero, and E. S. Curtoni, "HLA polymorphisms in Italian bone marrow donors: a regional analysis," Tissue Antigens, vol. 52, no. 2, pp. 135-146, 1998.

[55] J. N. Torimiro, J. K. Carr, N. D. Wolfe et al., "HLA class I diversity among rural rainforest inhabitants in Cameroon: identification of A*2612-B*4407 haplotype," Tissue Antigens, vol. 67, no. 1, pp. 30-37, 2006.

[56] J. M. Ellis, S. J. Mack, R. F. Leke, I. Quakyi, A. H. Johnson, and C. K. Hurley, "Diversity is demonstrated in class I HLA-A and HLA-B alleles in Cameroon, Africa: description of HLAA*03012, *2612, *3006 and HLA-B*1403, *4016, *4703," Tissue Antigens, vol. 56, no. 4, pp. 291-302, 2000. 
[57] H. Spínola, J. Bruges-Armas, D. Middleton, and A. Brehm, "HLA polymorphisms in Cabo Verde and Guiné-Bissau inferred from sequence-based typing," Human Immunology, vol. 66, no. 10, pp. 1082-1092, 2005.

[58] J. Bruges Armas, G. Destro-Bisol, A. López-Vazquez et al., "HLA class I variation in the West African Pygmies and their genetic relationship with other African populations," Tissue Antigens, vol. 62, no. 3, pp. 233-242, 2003.

[59] K. Cao, A. M. Moormann, K. E. Lyke et al., "Differentiation between African populations is evidenced by the diversity of alleles and haplotypes of HLA class I loci," Tissue Antigens, vol. 63, no. 4, pp. 293-325, 2004.

[60] A. A. A. Assane, G. M. Fabricio-Silva, J. Cardoso-Oliveira et al., "Human leukocyte antigen-A, -B, and -DRB1 allele and haplotype frequencies in the Mozambican population: a blood donor-based population study," Human Immunology, vol. 71, no. 10, pp. 1027-1032, 2010.

[61] J. Tang, E. Naik, C. Costello et al., "Characteristics of HLA class I and class II polymorphisms in Rwandan women," Experimental and Clinical Immunogenetics, vol. 17, no. 4, pp. 185-198, 2000.

[62] N. Saldanha, C. Spínola, M. R. Santos et al., "HLA polymorphisms in Forros and Angolares from Sao Tome Island (West Africa): evidence for the population origin," Journal of Genetic Genealogy, vol. 5, no. 2, pp. 76-85, 2009.

[63] A. Sanchez-Mazas, Q. G. Steiner, C. Grundschober, and J. M. Tiercy, "The molecular determination of HLA-Cw alleles, in the Mandenka (West Africa) reveals a close genetic relationship between Africans and Europeans," Tissue Antigens, vol. 56, no. 4, pp. 303-312, 2000.

[64] M. Paximadis, T. Y. Mathebula, N. L. Gentle et al., "Human leukocyte antigen class I, (A, B, C) and II, (DRB1) diversity in the black and Caucasian South African population," Human Immunology, vol. 73, no. 1, pp. 80-92, 2012.

[65] G. H. Kijak, A. M. Walsh, R. N. Koehler et al., "HLA class $\mathrm{i}$ allele and haplotype diversity in Ugandans supports the presence of a major east African genetic cluster," Tissue Antigens, vol. 73, no. 3, pp. 262-269, 2009.

[66] H. Kaiser, "The application of electronic computers to factor analysis," Educational and Psychological Measurement, vol. 20, pp. 141-151, 1960.

[67] S. L. Bonatto and F. M. Salzano, "Diversity and age of the four major mtDNA haplogroups, and their implications for the peopling of the New World," American Journal of Human Genetics, vol. 61, no. 6, pp. 1413-1423, 1997.

[68] B. Bertoni, B. Budowle, M. Sans, S. A. Barton, and R. Chakraborty, "Admixture in Hispanics: distribution of ancestral population contributions in the continental United States," Human Biology, vol. 75, no. 1, pp. 1-11, 2003.

[69] R. Kosoy, R. Nassir, C. Tian et al., "Ancestry informative marker sets for determining continental origin and admixture proportions in common populations in America," Human Mutation, vol. 30, no. 1, pp. 69-78, 2009.

[70] S. Wang, N. Ray, W. Rojas et al., "Geographic patterns of genome admixture in Latin American Mestizos," PLoS Genetics, vol. 4, no. 3, Article ID e1000037, 2008.

[71] L. G. Carvajal-Carmona, R. Ophoff, S. Service et al., "Genetic demography of Antioquia (Colombia) and the Central Valley of Costa Rica," Human Genetics, vol. 112, no. 5-6, pp. 534-541, 2003.

[72] A. Cintado, O. Companioni, M. Nazabal et al., "Admixture estimates for the population of Havana City," Annals of Human Biology, vol. 36, no. 3, pp. 350-360, 2009.
[73] A. A. Vernaza-Kwiers, I. J. de Gómez, M. Díaz-Isaacs, C. J. Cuero, E. Pérez Guardia, and M. Moreno Saavedra, "Gene frequency and haplotypes of the HLA system in the Panamanian population," Revista Médica de Panamá, vol. 20, no. 3, pp. 116123, 1995.

[74] E. A. Santiago-Delpín, S. De Echegaray, F. Rivera-Cruz, and A. Rodríguez-Trinidad, "The histocompatibility profile of the Puerto Rican population," Transplantation Proceedings, vol. 34, no. 8, pp. 3075-3078, 2002.

[75] I. Alvarez, M. Bengochea, R. Toledo, E. Carretto, and P. C. Hidalgo, "HLA class I antigen and HLA-A, -B, and -C haplotype frequencies in Uruguayans," Human Biology, vol. 78, no. 4, pp. 513-525, 2006.

[76] S. J. Easaw, D. E. Lake, M. Beer, K. Seiter, E. J. Feldman, and T. Ahmed, "Graft-versus-host disease. Possible higher risk for African American patients," Cancer, vol. 78, no. 7, pp. 14921497, 1996.

[77] K. S. Baker, S. M. Davies, N. S. Majhail et al., "Race and socioeconomic status influence outcomes of unrelated donor hematopoietic cell transplantation," Biology of Blood and Marrow Transplantation, vol. 15, no. 12, pp. 1543-1554, 2009.

[78] P. N. Hari, N. S. Majhail, M. J. Zhang et al., "Race and outcomes of autologous hematopoietic cell transplantation for multiple myeloma," Biology of Blood and Marrow Transplantation, vol. 16, no. 3, pp. 395-402, 2010.

[79] Y. Morishima, "Impact of donor-recipient ethnicity on risk of acute graft-versus-host disease, leukemia relapse and survival in hematopoietic stem cell transplantation from HLAcompatible unrelated donors," in Proceedings of the 51st ASH Annual Meeting and Exposition, A Report From the International Histocompatibility Workshop Group, New Orleans, Miss, USA, 2009.

[80] M. Remberger, J. Aschan, B. Lönnqvist et al., "An ethnic role for chronic, but not acute, graft-versus-host disease after HLAidentical sibling stem cell transplantation," European Journal of Haematology, vol. 66, no. 1, pp. 50-56, 2001.

[81] D. S. Serna, S. J. Lee, M. J. Zhang et al., "Trends in survival rates after allogeneic hematopoietic stem-cell transplantation for acute and chronic leukemia by ethnicity in the United States and Canada," Journal of Clinical Oncology, vol. 21, no. 20, pp. 3754-3760, 2003.

[82] K. S. Baker, F. R. Loberiza, H. Yu et al., "Outcome of ethnic minorities with acute or chronic leukemia treated with hematopoietic stem-cell transplantation in the United States," Journal of Clinical Oncology, vol. 23, no. 28, pp. 7032-7042, 2005.

[83] S. C. Hoffmann, E. M. Stanley, E. D. Cox et al., "Ethnicity greatly influences cytokine gene polymorphism distribution," American Journal of Transplantation, vol. 2, no. 6, pp. 560-567, 2002.

[84] G. Suarez-Kurtz, J. P. Genro, M. O. de et al., "Global pharmacogenomics: impact of population diversity on the distribution of polymorphisms in the CYP2C cluster among Brazilians," Pharmacogenomics Journal, vol. 12, no. 3, pp. 267276, 2012.

[85] G. Suarez-Kurtz and S. D. J. Pena, "Pharmacogenomics in the Americas: the impact of genetic admixture," Current Drug Targets, vol. 7, no. 12, pp. 1649-1658, 2006.

[86] B. Morera, R. Barrantes, and R. Marin-Rojas, "Gene admixture in the Costa Rican population," Annals of Human Genetics, vol. 67, no. 1, pp. 71-80, 2003. 
[87] T. C. Lins, R. G. Vieira, B. S. Abreu et al., "Genetic heterogeneity of self-reported ancestry groups in an admixed Brazilian population," Journal of Epidemiology, vol. 21, no. 4, pp. 240-245, 2011.

[88] K. Hunley and M. Healy, "The impact of founder effects, gene flow, and European admixture on native American genetic diversity," American Journal of Physical Anthropology, vol. 146, no. 4, pp. 530-538, 2011. 


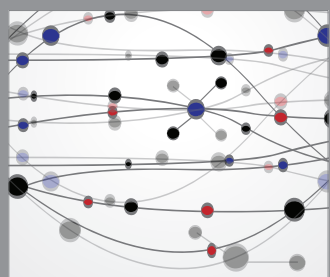

The Scientific World Journal
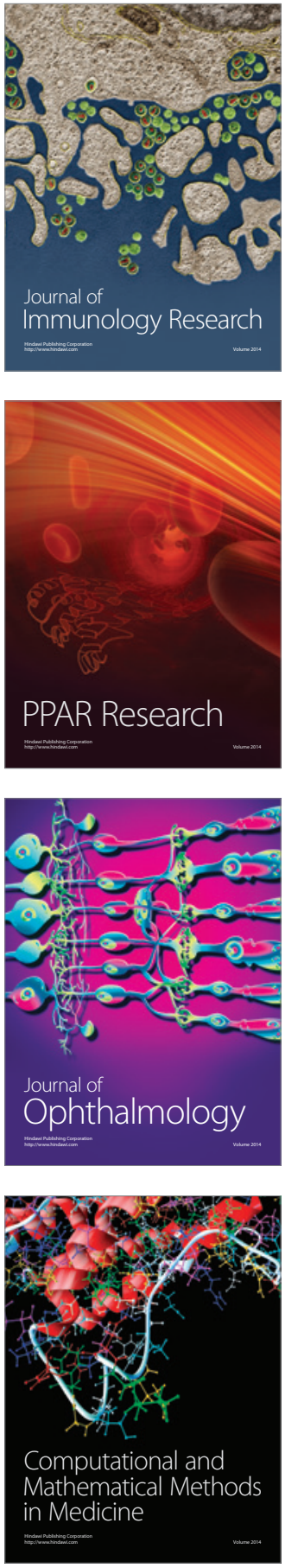

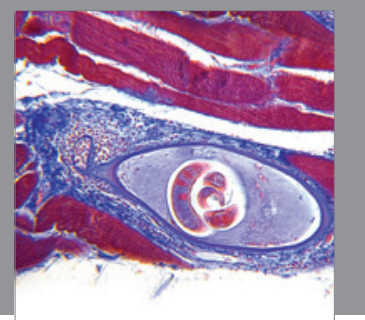

Gastroenterology

Research and Practice
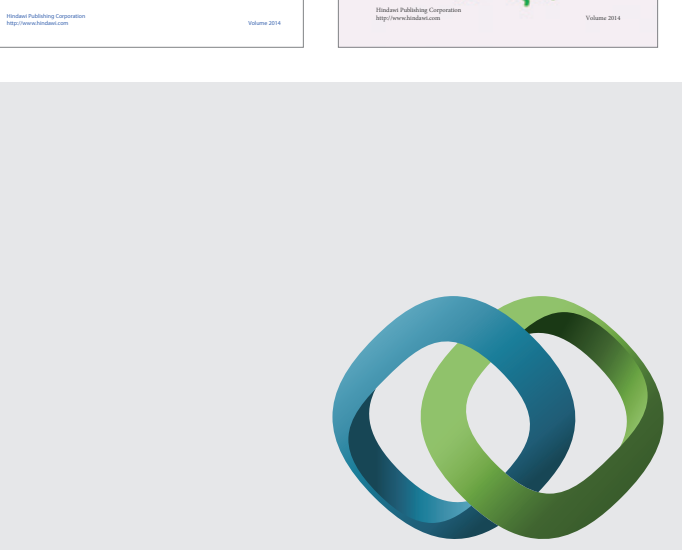

\section{Hindawi}

Submit your manuscripts at

http://www.hindawi.com
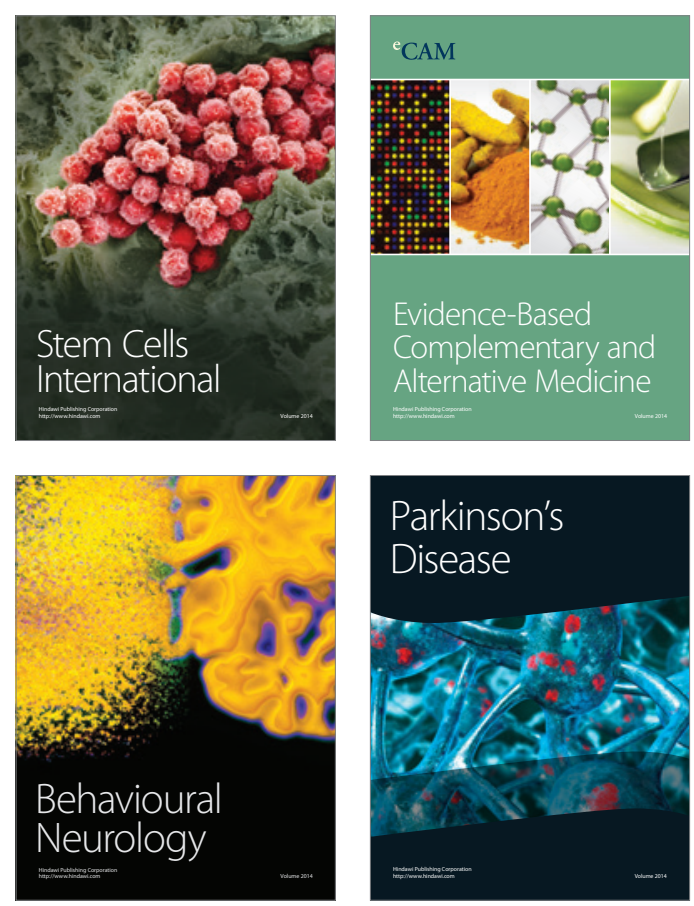

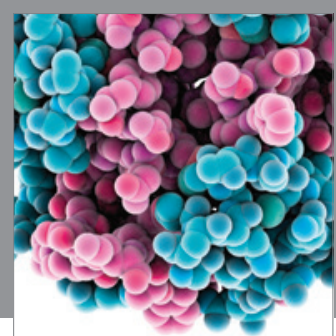

Journal of
Diabetes Research

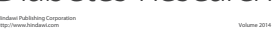

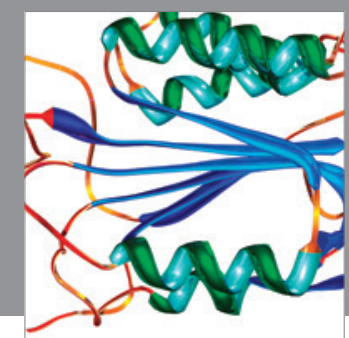

Disease Markers
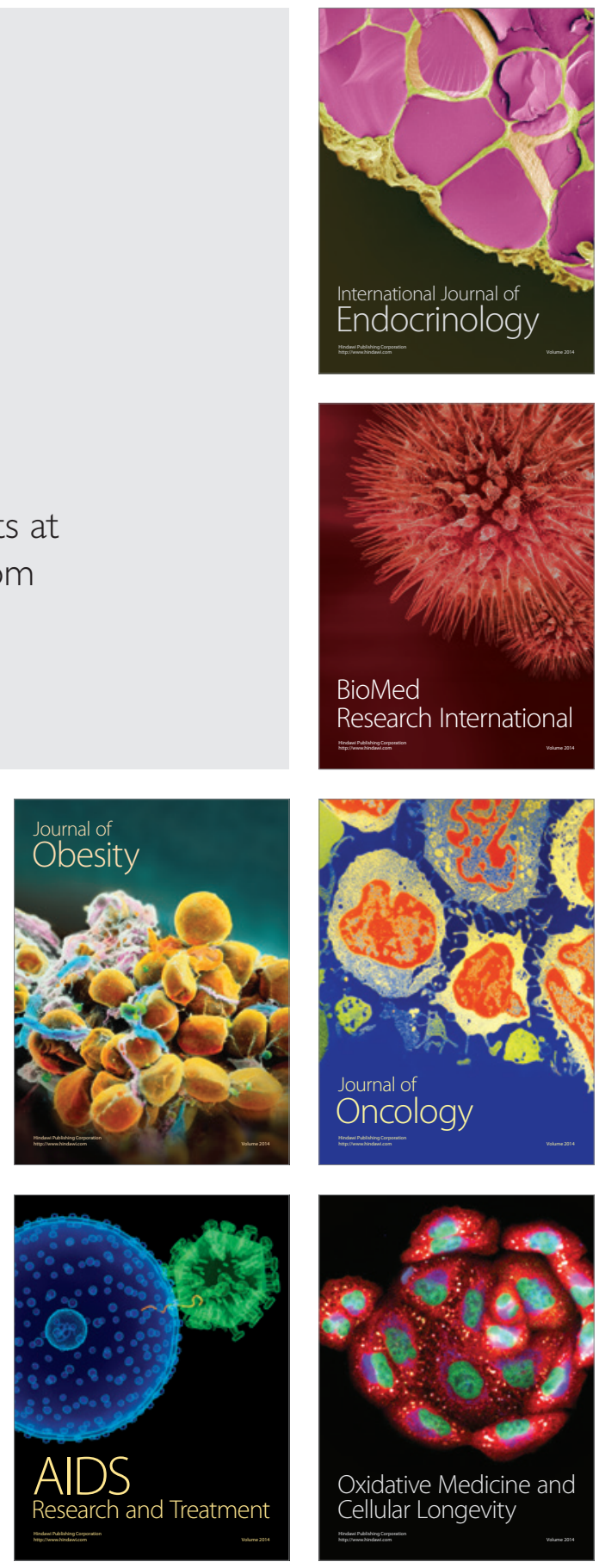